P-ISSN : 2655-9811, E-ISSN : 2656-1964

J. Fe asible., Vol. 3, N 0.1, Februari $2021(1-12)$

(c) 2019 Pusat In kubasiB isn is dan Kew irausahaan

Universitas Pamulang (PINBIKUNPAM)
JURNAL ILMIAH

FEASI BLE

\title{
Pemanfaatan Digital Marketing Pada Koperasi Dan Cara Koperasi Menghadapi Financial Technology (Studi Kasus pada BMT Al-Fath IKMI)
}

\author{
Fathorrahman $^{1}$, Khayatun Nufus ${ }^{2^{*}}$ \\ ${ }^{1}$ Fakultas Ekonomi Universitas Pamulang; dosen01040@unpam.ac.id \\ ${ }^{2}$ Fakultas Ekonomi dan Bisnis UIN Jakarta; nufus_awal@yahoo.co.id*
}

\begin{abstract}
Abstrak
Penelitian ini bertujuan untuk mengatahui pemanfaatan digital marketing pada koperasi dan bagaimana cara koperasi menghadapi financial techonolgy dengan memilih BMT Al-Fath IKMI sebagai objek penelitian. Metodelogi pencarian datanya menggunakan data sekunder dan data internal. hasil penelitian ini adalah BMT Al-Fath IKMI mempromosikan produknya melalui brosur dan memanfaatkan digital marketing seperti website dan Instagram dalam mempromosikan produknya. Sejauh ini, BMT Al-Fath IKMI belum memiliki cara menghadapi perkembangan Financial Technology (Fintech).
\end{abstract}

Kata Kunci : Koperasi; Digital Marketing; Financial Technology; BMT Al-Fath IKMI

\begin{abstract}
This study aims to determine the use of digital marketing in cooperatives and how cooperatives face financial technology by choosing BMT Al-Fath IKMI as the object of research. The data search methodology uses secondary data and internal data. The result of this research is that BMT Al-Fath IKMI promotes its products through brochures and utilizes digital marketing such as websites and Instagram in promoting its products. So far, BMT Al-Fath IKMI has no way of dealing with the development of Financial Technology (Fintech).
\end{abstract}

Keywords: Cooperative; Digital Marketing; Financial Technology; BMT Al-Fath IKMI

$\left.{ }^{*}\right)$ Korespondensi penulis 


\section{PENDAHULUAN}

Lembaga keuangan adalah lembaga yang memberikan fasilitas dan produk di bidang keuangan serta memutar arus uang dalam perekonomian. Kegiatan operasional dasar dari lembaga keuangan adalah menghimpun dana dari masyarakat dan menyalurkannya lagi kepada masyarakat yang membutuhkan dana. Saat ini, sudah ada berbagai jenis lembaga keuangan nonbank yang berkembang di Indonesia yang berfungsi menyalurkan dana dan menghimpun dana salah satunya adalah koperasi atau BMT.

Koperasi adalah organisasi ekonomi yang dimiliki dan dioperasikan oleh anggotanya demi kepentingan bersama. Tujuan koperasi yang paling utama adalah untuk mensejahterakan anggotanya, termasuk dari segi finansial dan ekonomi. Tetapi, kenyataan yang terjadi saat ini adalah minat masyarakat untuk berkoperasi sangat rendah. Padahal jika dilihat dari kegiatannya, koperasi menjalankan kegiatannya berdasarkan asas kekeluargaan dan gotong royong. Koperasi diharapkan dapat mendorong perekonomian rakyat dan mensejahterakan rakyat. Tantangan koperasi yang dihadapi saat ini harus bersaing dengan lembaga keuangan lainnya.

Oleh karena itu penulis akan menjabarkan ke dalam tulisan ini tentang Pemanfaatan digital marketing BMT AlFath IKMI, dan Cara BMT Al-Fath IKMI menghadapi Financial Technology (Fintech).

\section{Koperasi}

Koperasi merupakan salah satu bentuk badan hukum yang sudah lama dikenal di Indonesia. pelopor pengembangan perkoperasian di Indonesia adalah Bung Hatta dan sampai saat ini beliau dikenal sebagai bapak koperasi Indonesia. Menurut Kasmir (2018: 252) "Koperasi adalah badan usaha dengan kepemilikan dan pemakai jasa merupakan anggota dari koperasi itu sendiri serta pengawasannya pun dilakukan oleh mereka yang menggunakan jasa/pelayanan badan usaha itu (Richard Kohl dan Abrahamson)". Sedangkan, menurut Undang-Undang Perkoperasian Bab 1 pasal 1 tahun 2012 koperasi adalah badan hokum yang didirikan oleh orang perseorangan atau badan hokum koperasi, dengan pemisahan kekayaan para anggotanya sebagai modal untuk menjalankan usaha yang memenuhi aspirasi dan kebutuhan bersama di bidang ekonomi, social, dan budaya sesuai dengan nilai dan prinsip koperasi.

Dalam praktiknya terdapat banyak jenis-jenis koperasi. Pendirian jenis koperasi tidak lepas dari keinginan para anggota koperasi tersebut. Dalam menjalankan kegiatannya, koperasi simpan pinjam memungut sejumlah uang dari setiap anggota koperasi. Uang yang dikumpulkan para anggota tersebut kemudian dijadikan modal untuk di kelola oleh pengurus koperasi, dipinjamkan kembali bagi anggota yang membutuhkannya.

Dapat disimpulkan bahwa koperasi merupakan badan usaha yang mengumpulkan dana dari para anggotanya sebagai modal serta dimiliki dan dioperasikan oleh para anggotanya untuk memenuhi kepentingan bersama yang dibentuk atas asas kekeluargaan, dimana tujuannya untuk mensejahterakan para anggotanya. Sebagai pemilik usaha, anggota koperasi juga harus berusaha dalam menyediakan kebutuhan yang diperlukan oleh sesama anggotanya. Adapun keuntungan yang diperoleh para anggota berasal dari SHU (Sisa Hasil Usaha) yang diberikan berdasarkan pada besarnya modal awal anggota dan partisipasi/keaktifan dari para anggotanya.

\section{Sumber-Sumber dana Koperasi}


Sumber dana merupakan hal yang sangat penting bagi kehidupan koperasi simpan pinjam dalam rangka memenuhi kebutuhan dana para anggotanya. Bagi anggota koperasi yang kelebihan dana diharapkan untuk menyimpan dananya di koperasi dan kemudian oleh pihak koperasi dipinjamkan kembali kepada para anggota yang membutuhkan dana dan jika memungkinkan koperasi juga dapat meminjamkan dananya kepada masyarakat luas.

Secara umum sumber dana koperasi berasal dari: 1) Para anggota koperasi, 2) Iuran wajib, 3) Iuran pokok, 4) Iuran sukarela, 5) Luar koperasi, 6) Pemerintah, 7) Perbankan, dan 8) Lembaga swasta lainnya

"Pembagian keuntungan diberikan kepada para anggota sangat tergantung kepada keaktifan para anggotanya dalam meminjamkan dana” (Kasmir: 2018, 253)

\section{Jenis-Jenis Koperasi}

Salah satu tujuan pendirian kopersi didasarkan kepada kebutuhan dan kepentingan para anggotnya. Masing-masing kelompok masyarakat yang mendirikan koperasi memiliki kepentingan ataupun tujuan yang berbeda. Perbedaan kepentingan ini menyebabkan koperasi dibentuk dalam beberapa jenis sesuai dengan kebutuhan kelompok tersebut. Jenisjenis koperasi yang ada dan berkembang di Indonesia: 1) Koperasi produksi, 2) Koperasi konsumsi, 3) Koperasi simpan pinjam, dan 4) Koperasi serba usaha.

Yang membedakan jenis koperasi tersebut adalah usaha yang mereka jalankan. Sebagai contoh untuk koperasi produksi diutamakan diberikan kepada para anggotanya dalam rangka berproduksi untuk menghasilkan barang mapun jasa. Produksi dapat dilakukan dalam berbagai bidang seperti pertanian atau industri atau jasa (Kasmir: 2018, 253).
Kemudian koperasi konsumsi dalam kegiatan usahanya adalah menyediakan kebutuhan akan barang-barang pokok sehari-hari seperti sandang, pangan, dan kebutuhan yang berbentuk barang lainnya. Koperasi jenis ini banyak dilakukan oleh karyawan suatu perusahaan dengan menyediakan berbagai kebutuhan bagi pra anggotanya (Kasmir: 2018, 253-254).

Sedangkan koperasi simpan pinjam elakukan usaha penyimpanan dan peminjanan sejumlah uang untuk keperluan para anggotanya. Koperasi jenis inisering disebut dengan koperasi kredit yang khusus menyediakan dana bagi anggota yang memerlukan dana dengan biaya murah.

\section{Keuntungan Koperasi}

Keuntungan dari koperasi adalah bunga yang dibebankan kepada peminjam. Semakin banyak uang yang disalurkkan akan memperbesar keuntungan koperasi. Di samping itu, keutungan lainnya adalah memperoleh biaya-biaya administrasi yang dibebankan kepada peminjam. Kemudian, keuntungan juga dapat diperoleh dari hasil investasi lain yang dilakukan di luar kegiatan pemnjaman misalnya penempatan uang dalam bidang surat-surat berharga.

\section{Pendirian Koperasi}

Pendirian lembaga koperasi cukup sederhana yaitu cukup dengan minimal 20 orang yang membuat kesepakatan dengan akte notaris, kemudian didaftarkan di kanwil Departemen Koperasi setempat untuk mendapatlan pengesahannya. Dalam susunan organisasi koperasi rapat pengurus mengangkat pengurus dan pengawas. Sedangkan kegiatan sehari-hari diserahkan kepada pengelola koperasi.

\section{Baitul Mal Wattamwil (BMT)}

Baitul Mal Wattamwil (BMT) adalah lembaga keuangan mikro yang dioperasikan 
dengan prinsip bagi hasil, menumbuh kembangkan bisnis usaha mikro dan kecil, dalam rangka mengangkat derajat dan martabat serta membela kepentingan kaum fakir miskin yang beroperasi sesuai dengan prinsip-prinsip syariah Islam yang tata cara beroperasinya mengacu kepada ketentuanketentuan Al-Qur'an dan Hadist. Baitul Mal Wattamwil (BMT) beroperasi mengikuti ketentuan-ketentuan syari'ah Islam khususnya yang menyangkut tata cara bermuamalat secara Islam. Dalam tata cara bermuamalat itu dijauhi praktek-praktek yang dikhawatirkan mengandung unsurunsur riba untuk diisi dengan kegiatankegiatan investasi atas dasar bagi hasil dan pembiayaan perdagangan.

Baitul tamwil memiliki fungsi dan tujuan untuk menghimpun dana dari anggota melalui produk produk simpanan BMT seperti: Simpanan Pokok, Simpanan Wajib, Simpanan Sukarela dan simpanan berjangka. Dalam simpanan ini, BMT berhak menggunakan dana sesuai pada prinsip syariah yang dicantumkan dalam akad ketika pembukaan rekening tabungan, BMT juga berkewajiban untuk mengembalikan dana tersebut apabila disuatu hari anggota ingin menarik dananya kembali. Selanjutnya BMT terus akan mengembangkan tiga pilar utama kegiatan ekonomi mereka yaitu baitul mall, baitul tamwil dan sektor rill yang digunakan untuk mengoptimalkan dan dari masyarakat.

Kata Baitul Mal diambil dari bahasa Arab, Baitul memiliki arti rumah dan Al-Mal memiliki arti harta. Jadi, Baitul Mal dapat disebut juga sebagai rumah untuk mengumpulkan atau menyimpan harta. Sedangkan Wattamwil diambil dari bahasa arab yang jika diartikan sebagai lembaga keuangan syariah yang berfokus pada pemberdayaan usaha kecil, menengah yang dinaungi oleh unit koperasi. Dalam sebuah koperasi didalamnya terdapat unit unit usaha antara lain: unit usaha riil, unit usaha jasa, dan unit usaha simpan pinjam. Dalam kasus ini, BMT menjalankan usaha koperasi simpan pinjam yang berlandaskan atas syariat islam. BMT mengutamakan sistem bagi hasil dibandingkan bunga yang didapatkan melalui koperasi syariah atau saat ini dikenal sebagai pengelolaan secara syariah (mudharabah dan musyarokah) yang direalisasikan dalam bentuk pembiayaan syariah.

\section{Akad-akad Perbankan Syariah}

a. Murabahah Akad jual beli dimana harga dan keuntungan disepakati antara penjual dan pembeli. Jenis dan Jumlah barang dijelaskan dengan rinci. Barang diserahkan setelah akad jual beli dan pembayaran bisa dilakukan secara mengangsur/cicilan atau sekaligus.

b. Salam Jual beli dengan cara pemesanan, di mana pembeli memberikan uang terlebih dahulu terhadap barang yang telah disebutkan spesifikasinya, dan barang dikirim kemudian, Salam biasanya dipergunakan untuk produkproduk pertanian jangka pendek. Dalam hal ini lembaga keuangan bertindak sebagai pembeli produk dan memberikan uangnya lebih dulu sedangkan para nasabah menggunakannya sebagai modal untuk mengelola pertaniannya.

c. Istishna' Jual beli barang dalam bentuk pemesanan pembuatan barang berdasarkan persyaratan serta kriteria tertentu, sedangkan pola pembayaran dapat dilakukan sesuai dengan kesepakatan (dapat dilakukan di depan atau pada saat pengiriman barang).

d. Mudharabah Akad yang dilakukan antara pemilik modal (shahibul mal) dengan pengelola (mudharib) dimana nisbah bagi hasil disepakati di awal, sedangkan kerugian ditanggung oleh pemilik modal. 
e. Mudharabah Muqayyadah Akad yang dilakukan antara pemilik modal untuk usaha yang ditentukan oleh pemilik modal (shahibul mal) dengan pengelola (mudharib), dimana nisbah bagi hasil disepakati di awal untuk dibagi bersama, sedangkan kerugian ditanggung oleh pemilik modal. Dalam terminologi perbankan syariah ini lazim disebut Special Investment.

f. Musyarakah Akad antara dua pemilik modal atau lebih untuk menyatukan modalnya pada usaha tertentu, sedangkan pelaksananya bisa ditunjuk salah satu dari mereka. Akad ini diterapkan pada usaha/proyek yang sebagiannya dibiayai oleh lembaga keuangan sedangkan selebihnya dibiayai oleh nasabah.

g. Musyarakah Mutanaqisah Akad antara dua pihak atau lebih yang berserikat atau berkongsi terhadap suatu barang dimana salah satu pihak kemudian membeli bagian pihak lainnya secara bertahap. Akad ini diterapkan pada pembiayaan proyek yang dibiayai oleh lembaga keuangan dengan nasabah atau lembaga keuangan lainnya dimana bagian lembaga keuangan secara bertahap dibeli oleh pihak lainnya dengan cara mencicil. Akad ini juga terjadi pada mudharabah yang modal pokoknya dicicil, sedangkan usaha itu berjalan terus dengan modal yang tetap.

h. Wadi'ah Akad yang terjadi antara dua pihak, dimana pihak pertama menitipkan suatu barang kepada pihak kedua. Lembaga keuangan menerapkan akad ini pada rekening giro.

i. Wakalah Akad perwakilan antara satu pihak kepada yang lain. Wakalah biasanya diterapkan untuk pembuatan Letter of Credit, atas pembelian barang di luar negeri (L/C Import) atau penerusan permintaan. j. Ijarah Akad sewa menyewa barang antara kedua belah pihak, untuk memperoleh manfaat atas barang yang disewa. Akad sewa yang terjadi antara lembaga keuangan (pemilik barang) dengan nasabah (penyewa) dengan cicilan sewa yang sudah termasuk cicilan pokok harga barang sehingga pada akhir masa perjanjian penyewa dapat membeli barang tersebut dengan sisa harga yang kecil atau diberikan saja oleh bank. Karena itu biasanya Ijarah ini dinamai dengan al Ijarah waliqtina' atau al Ijarah alMuntahia Bittamliik.

k. Kafalah Akad jaminan satu pihak kepada pihak lain. Dalam lembaga keuangan biasanya digunakan untuk membuat garansi atas suatu proyek (performance bond), partisipasi dalam tender (tender bond) atau pembayaran lebih dulu (advance payment bond).

1. Hawalah Akad pemindahan utang/ piutang suatu pihak kepada pihak yang lain. Dalam lembaga keuangan hawalah diterapkan pada fasilitas tambahan kepada nasabah pembiayaan yang ingin menjual produknya kepada pembeli dengan jaminan pembayaran dari pembeli tersebut dalam bentuk giro mundur. Ini lazim disebut Post Dated Check. Namun disesuaikan dengan prinsip-prinsip Syariah.

m. Rahn Akad menggadaikan barang dari satu pihak kepada pihak yang lain, dengan uang sebagai gantinya. Akad ini digunakan sebagai akad tambahan pada pembiayaan yang berisiko dan memerlukan jaminan tambahan. Lembaga keuangan tidak menarik manfaat apapun kecuali biaya pemeliharaan atau keamanan barang tersebut.

n. Qard Pembiayaan kepada nasabah untuk dana talangan segera dalam jangka waktu yang relatif pendek, dan dana tersebut akan dikembalikan secepatnya 
sejumlah uang yang digunakannya. Dalam transaksi ini, nasabah hanya mengembalikan pokok.

\section{Pengertian Digital Marketing}

Digital marketing adalah segala upaya untuk melakukan pemasaran suatu produk dan jasa melalui media internet. Pemasaran dalam internet marketing bukan hanya untuk meningkatkan penjualan, tapi juga termasuk promosi produk dan jasa baru, branding, dan membina hubungan dengan pelanggan. Berikut adalah jenis-jenis digital marketing:

a. Website, merupakan persyaratan utama untuk menang dalam persaingan digital. Data menunjukkan bahwa 97\% konsumen mencari produk maupun jasa yang akan digunakan melalui internet. Dapat pula dikatakan website adalah "toko digital" bagi bisnis Anda yang bahkan dapat menggantikan keberadaan toko fisik maupun tenaga penjualan konvensional.

b. Search Engine Marketing, adalah upaya untuk membuat website perusahaan Anda mudah ditemukan dalam mesin pencari sejenis google. Untuk dapat berada di halaman pertama mesin pencari sekelas google, dibutuhkan waktu yang lama dan teknik khusus untuk menerapkannya.

c. Social Media Marketing, pengguna social media yang terus meningkat untuk berbagai keperluan seperti sarana komunikasi, berkumpul-nya komunitas bahkan sebagai media mencari informasi, kini juga semakin dioptimalkan pengusaha sebagai sarana promosi bisnis mereka. Beredarnya berbagai platform sosial media seperti Facebook, Instagram, Linkedin, Twitter, Youtube dan lain sebagainya, membuat penyebaran informasi menjadi lebih cepat dan menjangkau lebih banyak orang. Selain itu, sosial media marketing juga digemari karena dapat dilakukan dengan biaya minim bahkan gratis. Selain dapat meningkatkan brand perusahaan, sosial media juga dimanfaatkan sebagai sarana komunikasi dan interaksi antara perusahaan dengan konsumen.

d. Online Advertising adalah media promosi atau periklanan melalui internet dengan cara berbayar. Online advertising sendiri memiliki beberapa pilihan yang beragam sesuai kebutuhan Anda, seperti Display Advertising, Social Media Advertising, PPC, Youtube Advertising, dan masih banyak lagi.

e. Email Marketing dapat memberikan informasi yang update seputar program promosi yang sedang berlangsung, maupun mem-perkenalkan produk atau jasa Anda yang baru. Email marketing juga membuat pelanggan Anda tidak ketinggalan akan informasi dari perusahaan Anda seperti kegiatan maupun berita terbaru.

\section{f. Financial Technology (FinTech)} merupakan sebuah era di mana kehidupan dan aktivitas masyarakat akan lebih mudah dan efektif dikarenakan peran dunia digital. Salah satu jenis startup yang mulai naik daun adalah pada bidang Fintech. Fintech adalah sebuah sebutan yang disingkat dari kata 'financial' dan 'technology' di mana artinya adalah sebuah inovasi di dalam bidang jasa keuangan. Inovasi yang ditawarkan Fintech sangat luas dan dalam berbagai segmen, baik itu B2B (Business to Business) hingga $\mathrm{B} 2 \mathrm{C}$ (Business to Consumer).

Beberapa contoh bisnis yang tergabung di dalam Fintech adalah Proses jual beli saham, Pembayaran, Peminjaman uang (lending) secara peer to peer, Transfer dana, Investasi ritel, 
Perencanaan keuangan (personal finance), dan lainnya. Fintech mempengaruhi kebiasaan transaksi masyarakat menjadi lebih praktis dan efektif. Fintech pun membantu masyarakat untuk lebih mudah mendapatkan akses terhadap produk keuangan dan meningkatkan literasi keuangan.

Berikut adalah 4 klasifikasi Fintech menurut Bank Indonesia:

\section{a. Crowdfunding dan Peer to Peer Lending}

Beberapa contoh startup fintech pada klasifikasi ini adalah Uang Teman.com dan TemanUsaha.com untuk contoh pembiayaan dalam bentuk utang, Wujudkan.com dan Kitabisa.com untuk contoh pembiayaan masal, Koinworks.com dan Danadidik.com untuk contoh peer to peer lending, Kredivo.com dan ShootYourDream.com untuk contoh cicilan tanpa kartu kredit.

b. Market Aggregator.

Contohnya, jika seorang konsumen ingin memilih produk KPR, platform Fintech akan menyesuaikan data finansial pribadi konsumen dan memberikan pilihan produk KPR sesuai dengan data pribadi yang dimasukkan. Pilihan ini akan diberikan sesuai dengan keinginan dan kemampuan finansial serta preferensi konsumen. Untuk contoh pembanding produk keuangan secara umum adalah Cekaja.com dan Kreditgogo.com, untuk pembanding produk asuransi yaitu RajaPremi. com dan Asuransi88.com.

\section{c. Risk and Investment Management.}

Beberapa contoh fintech untuk jenis ini adalah NgaturDuit.com dan
Dompet Sehat sebagai contoh pelacak pengeluaran untuk pribadi. Jurnal.id dan Sleekr sebagai contoh pelacak pengeluaran untuk UMKM dan pengatur pajak seperti OnlinePajak.com.

d. Payment, Settlement dan Clearing.

Jenis Fintech yang tergabung di dalam klasifikasi ini adalah pembayaran (payments) seperti payment gateway dan e-wallet. Klasifikasi ini diawasi oleh BI (Bank Indonesia) karena proses pembayaran ini juga meliputi perputaran uang yang nantinya akan menjadi tanggung jawab Bank Indonesia. Beberapa contoh perusahaan Fintech dalam bidang pembayaran adalah DoKu, Kartuku (perusahaan pembayaran), Sakuku BCA, Uangku Smartfren (perusahaan pembayaran dengan mobile), GCI Indonesia (Gift Card), dan lainnya.

\section{METODE}

Menurut cara memperolehnya, ini adalah data sekunder yaitu data yang didapatkan tidak secara langsung dari objek atau subjek penelitian. Menurut sumbernya ini merupakan data internal yaitu data yang menggambarkan keadaan atau kegiatan dalam sebuah organisasi.

\section{HASIL dan PEMBAHASAN}

BMT AL-FATH IKMI merupakan Koperasi yang berdasarkan prinsip Syariah. Berdiri pada tanggal 13 Oktober 1996, didirikan oleh 25 orang pendiri yang sebagian besarnya adalah Anggota Pengajian Ikatan Masjid Indonesia (IKMI). Pendirian BMT AL-FATH IKMI dilatar belakangi oleh keprihatinan terhadap kondisi masyarakat, khususnya para pedagang di pasar tradisional Ciputat yang mereka memiliki 
potensi untuk berkembang namun tidak ada wadah yang mengakomodir sehingga banyak yang terjerat praktek riba oleh para rentenir.

Sebagai lembaga keuangan aset ummat, BMT AL-FATH IKMI berupaya memberdayakan ekonomi ummat secara berjamaah melalui kegiatan penyimpanan dan pembiayaan, serta peduli terhadap masyarakat tidak mampu melalui 4 program sosial: Insan Sehat, Insan Cerdas, Insan Mulya, dan Insan Mandiri.

\section{Legalitas BMT Al-Fath IKMI}

Nama : KSPPS BMT Al-Fath IKMI

Pendirian: 13 Oktober 1996

Badan Hukum: 650/BH/KWK.10/VI/1998

Persetujuan PAD: 0o0528/PAD/M.KUKM.

2/I/2018

NPWP : 02.021.735-2.411.000

SISP $\quad: 391 /$ SISP/Dep.1/III/2018

Sertifikat NIK : 3674060040007

Visi, Misi, dan Tujuan

BMT Al-Fath IKMI

\section{Visi}

Menjadi Koperasi Syariah yang terbaik.

Misi

1. Meningkatkan potensi ummat sehingga mampu berperan sebagai khalifah Allah yang berorientasi pada pengembangan dan pemberdayaan ummat menuju kepada masyarakat yang mandiri serta Islami.

2. Menjalankan kegiatan Simpan Pinjam dan Pembiayaan Syariah secara efektif, efisien, transparan, dan akuntabel.

3. Menyelenggarakan pelayanan prima pada Anggota, Anggota Luar Biasa, dan masyarakat sesuai jati diri Koperasi.

4. Menjalin kerjasama usaha dengan berbagai pihak yang halal dan saling menguntungkan.

5. Menjalankan peran sebagai lembaga dakwah bagi ummat untuk terciptanya keseimbangan masyarakat yang berkeadilan, sejahtera, kasih sayang, peduli, dan membawa manfaat bagi masyarakat luas.

\section{Tujuan}

1. Menjadi tempat bagi pemberdayaan masyarakat dhuafa.

2. Menumbuhkembangkan ekonomi syariah di tingkat usaha mikro, kecil, dan menengah guna memacu pertumbuhan

3. Usaha yang berdampak pada peningkatan kesejahteraan Anggota, Anggota Luar Biasa, dan masyarakat.

4. Meningkatkan semangat, peran serta Anggota, Anggota Luar Biasa, dan masyarakat dalam kegiatan Koperasi

5. Memperkuat kelembagaan dan memperluas jaringan kerja melalui kerjasama dengan berbagai potensi ummat,

6. Bersinergi dengan lembaga-lembaga keuangan syariah.

7. Mengembangkan program kerjasama (linkage programme) dengan lembagalembaga keuangan syariah sebagai agen dalam memberdayakan usaha mikro, kecil, dan menengah.

8. Mendukung terciptanya jaringan kerjasama antar Koperasi atau Koperasi Simpan Pinjam dan Pembiayaan Syariah di dalam negeri dan luar negeri.

\section{Budaya Kerja}

Budaya kerja sangat penting sebagai cerminan prilaku Pengelola BMT AL-Fath IKMI dalam melakukan kegiatan layanan dan operasional. Budaya Kerja BMT AL-Fath IKMI:

1. Kerja Ikhlas, Kerja Cerdas, dan Kerja Keras

2. Menjujung tinggi sifat Shidiq, Amanah, Fathanah, dan Tabligh.

3. Memberikan pelayanan dengan penuh perhatian dan profesional.

4. Pengelolaan usaha yang bersih, efisien, efektif, transparan, dan akuntabel. 
5. Selalu berupaya menciptakan lingkungan kerja yang nyaman dan menyenangkan.

\section{Cabang BMT Al-Fath IKMI}

1. Kantor Cabang Utama dan Kantor Baitul Mal: Jln. Aria Putra No.7, Kedaung, Pamulang, Tangerang Selatan. Telp: (o21) 740545859

2. Kantor Cabang Jombang: Jalan Jombang raya, Ruko Villa Jombang Baru D1/9. Jombang, Ciputat, Tangerang Selatan. Telp: (021) 74639280

3. Kantor Cabang Legoso: Jln. Legoso Raya, Ruko Grand Puri Laras Blk R No.1, Ciputat Timur, Tangerang Selatan. Telp/Fax: (021) 7412495

4. Kantor Cabang Pondok Aren: Jalan Pesantren Ruko 2 Perumahan Mutiara Bintaro. RT o3 RW 03. Jurangmangu Timur, Pondok Aren, Tanngerang Selatan. Telp: (o21) 22736667.

\section{Penyaluran Dana (Pembiayaan / Lending / Finance)}

Pembiayaan Syariah adalah pembiayaan yang diperuntukkan untuk memenuhi kebutuhan modal kerja atau usaha, pemenuhan kebutuhan hidup (pembelian rumah tinggal, tanah, kendaraan, pendidikan anak, dll) bagi usaha mikro dan kecil dengan akad-akad syariah.

\section{Keunggulan:}

1. Proses lebih cepat.

2. Untuk pelunasan dipercepat, tidak ada penalty.

3. Biaya admin sesuai biaya riil, tidak ada biaya provisi.

4. Tidak ada denda keterlambatan.

5. Plafond mulai dari Rp2.000.00o,sampai Rp200.000.000,-

6. Jangka waktu maksimal 5 tahun.

\section{Persyaratan:}

1. Telah menjadi Anggota BMT Al-Fath IKMI dengan membuka simpanan anggota minimal Rp25.000,-
2. Bagi wirausaha, usaha harus telah berjalan minimal 1 tahun.

3. Mengisi formulir Permohonan Pembiayaan dengan melampirkan:

a) Fotocopy KTP 3 lembar suami dan istri, KK, dan Surat Nikah.

b) Pas Foto berwarna terbaru ukuran 3x4, suamidan istri, @2 lembar.

c) Fotocopy jaminan (BPKB+STNK, SHM, SHGB +SPT PBB)

d) Bagi pegawai tambah fotocopy SK pegawai, slip gaji 3 bulan terakhir atau mutasi buku bank.

\section{Produk Perusahaan}

Kegiatan yang dilaksanakan BMT Alfath IKMI bergerak di setor bisnis (Tijarah). BMT Al-Fath IKMI memiliki tiga produk yaitu penghimpunan

1. Penghimpunan Dana

Pada produk ini BMT AL-Fath IKMI memiliki dua prinsip yaitu berdasarkan prinsip titipan (wadiah) dan prinsip bagi hasil.

a. Prinsip Titipan (Wadiah) yaitu Tabungan Wadiah BMT Al-Fath atau disebut juga dengan TAWAKAL. Penyetoran dan Penarikannya dapat dilakukan setiap saat sesuai jam kerja. Karena prinsipnya titipan (wadiah) maka anggota tidak mendapatkan bagi hasil.

b. Prinsip Bagi Hasil yaitu BMT ALFath IKMI sebagai Mudharib/ Pengelola diberikan kebebasan untuk mengelola investasi anggota tersebut untuk usaha produktif dan menguntung-kan. Keuntungan usaha dari pengelolaan Simpanan dibagi ber-dasarkan kesepakatan bersama atas dasar nisbah. Jika terjadi kerugian usaha bukan karena kelalaian, maka kerugian financial tersebut menjadi tanggung jawab Shahibul Maal, sementara Mudharib 
menanggung kerugian waktu dan tenaga. Pilihan jangka waktu Tabah mulai dari 3-12 bulan. Yang lainnya adalah SIDIK (Simpanan Pendidikan), Simpanan Idul Fitri, Simpanan Qurban, Simpanan Nikah dan Simpanan Haji dan Umroh.

2. Pembiayaan Syariah adalah pembiayaan yang diperuntukan guna memenuhi kebutuhan modal usaha atau pemenuhan kebutuhan barang atau jasa anggota dengan akad syariah. Keunggul-an pembiayaan syariah di BMT Al-Fath IKMI adalah proses yang lebih cepat. Anggota juga tidak akan dikenalan penalty ketika ingin melakukan pelunasan lebih cepat dan tidak ada denda keterlambatan. Biaya admin yang dikenakan pun sesuai dengan biaya riil. Pembiayaan syariah memberikan biaya mulai dari $>2$ juta sampai dengan 200 juta dengan jangka waktu maksimal 5 tahun. Pembiayaan syariah memiliki 4 jenis yaitu:

a. Pembiayaan Mudharabah, merupakan pembiayaan dengan pola kerjasama dimana sumber modal 100\% diberikan oleh BMT Al-Fath IKMI dan anggota sebagai pengelola. Keuntungan usaha dibagi sesuai nisbah kesepakatan.

b. Pembiayaan Musyarakah, merupakan pembiayaan dengan pola kerjasama dimana sumber modal dari 2 pihak yaitu BMT Al-Fath IKMI dan anggota. Keuntungan dibagi sesuai nisbah kesepakatan. Jika usaha rugi bukan karena salah kelola kerugian ditanggung bersama sesuai porsi modal yang ditanamkan.

c. Pembiayaan Ijarah, merupakan pembiayaan sewa menyewa manfaat suatu barang/jasa, antara BMT dan anggota. Harga sewa dan jangka waktu sesuai kesepakatan. d. Pembiayaan Murabahah, merupakan pembiayaan dengan sistem jual beli barang antara BMT Al-Fath IKMI dan anggota seharga perolehan ditambah keuntungan atau margin yang disepakati. Pem-bayaran diangsur sesuai kesepakat-an. Harga tidak akan berubah atau tetap sampai pembiayaan lunas.

\section{Teknologi Informasi BMT Al-Fath IKMI}

Saat ini BMT AL-FATH IKMI telah online (terhubung ke Internet) dan saling interkoneksi ke seluruh Cabang, sehingga Anggota dapat real time melakukan transaksi baik simpanan maupun angsuran pembiayaan di seluruh Cabang. Dengan sistem ini, bagi hasil simpanan juga telah dilakukan secara konsolidasi.

Dengan dukungan hardware dan software original serta tenaga IT yang handal, kami telah mengembangkan software keuangan sendiri, menjadikan sistem keuangan BMT mampu bekerja sesuai kebutuhan secara optimal dengan kecepatan yang memadai. Penggunaan piranti lunak dan Sistem Operasi yang legal dan halal, baik itu yang merupakan jenis freeware maupun software berbayar, merupakan komitmen kami sebagai pelaku Koperasi Syariah. Selain itu, BMT AL-FATH IKMI juga akan mengembangkan sistem keuangan berbasis Mobile System Transaction (MST), sehingga akan dapat melayani transaksi di luar kantor dengan real time juga.

Dan sebagai media informasi dan publikasi, BMT AL-FATH IKMI juga telah memiliki website resmi: bmtalfath.com, yang mempublikasi infomasi-informasi dan kegiatan BMT AL-FATH IKMI.

\section{Pemanfaatan Digital Marketing BMT Al-Fath IKMI}


BMT Al Fath IKMI berusaha mengikuti perkembangan teknologi. Dengan didukung dengan Tenaga IT yang handal, BMT Al-Fath IKMI mengembangkan website https://www.bmtalfath.com. Selain website, jenis digital marketing yang digunakan BMT Al-Fath IKMI adalah Social Media Marketing. Social media yang digunakan BMT Al-Fath IKMI adalah Instagram. Tetapi, pemanfaatan digital marketing yang dilakukan BMT Al-Fath IKMI dinilai belum maksimal. Website BMT Al-Fath IKMI hanya digunakan sebagai media publikasi dan informasi. Selain itu, pemanfaatan digital marketing ini dinilai belum mampu untuk meningkatkan jumlah anggota dan meningkatkan kesadaran masyrakat untuk berkoperasi. Kebanyakan masyarakat umum mengetahui tentang keberadaan BMT AlFath IKMI melalui brosur yang dibagikan.

\section{Cara BMT Al-Fath IKMI menghadapi Financial Technology (Fintech)}

BMT Al-Fath IKMI sendiri masih awam dengan istilah Financial Technology. Sehingga, belum ada tindakan preventif yang diambil oleh BMT Al-Fath IKMI untuk menghadapi perkembangan Financial Technology (FinTech). Saat ini, BMT hanya berfokus mengembangkan mobile apps untuk meningkatkan minat dan kesadaran masyrakat untuk berkoperasi sehingga tidak banyak lagi masyarakat yang terjerat dengan para rentenir/bank keliling. Selain itu, melalui pengembangan mobile apps ini, diharapkan dapat memudahkan anggota mengakses layanan BMT Al-Fath IKMI.

\section{SIMPULAN}

BMT Al-Fath IKMI telah berdiri selama 23 tahun dan telah memiliki 4 cabang yang berada di wilayah Tangerang Selatan yaitu Kedaung, Jombang, Legoso, dan Pondok Aren. Produk utama BMT Al-Fath IKMI yaitu Penghimpunan dana, Pem- biayaan syariah, dan Payment point. BMT AlFath IKMI mengelola produknya dengan baik. Saat ini, BMT Al-Fath IKMI telah memiliki sistem keuangan sendiri yang telah terintergrasi dengan cabang BMT Al-Fath IKMI lainnya. BMT Al-Fath IKMI telah memiliki banyak anggota karena persyaratan menjadi anggota yang mudah serta besaran simpanan pokok, wajib, dan sukarela BMT Al-Fath IKMI yang ringan dan tidak memberatkan anggotanya.

BMT Al-Fath IKMI mempromosikan produknya melalui brosur dan memanfaatkan digital marketing seperti website dan Instagram dalam mempromosikan produknya. Sejauh ini, BMT Al-Fath IKMI belum memiliki cara menghadapi perkembangan Financial Technology (Fintech).

\section{DAFTAR PUSTAKA}

Kasmir. 2018. Bank dan Lembaga Keuangan Lainnya. Depok: Rajawali Pers

Setiati Utami dkk. 2019. BMT Al-Fath IKMI. Makalah

https://www.bmtalfath.com

http://www.definisi-

pengertian.com/2015/05/definisipengertian-baitul-mal-

wattamwil.html?m=1 diakses pada 17-01-2020 pukul 16.20 WIB.

https://www.bankmuamalat.co.id/edukasi-

perbankan/mengenal-akad-

perbankan-syariah diakes pada 1701-2020 pukul 16.30 WIB.

https://www.seputarmarketing.com/ind/pe ngertian-dan-jenis-digitalmarketing/ diakes pada 17-01-2020 17.00 WIB.

www.finansialku.com/definisi-fintechadalah/amp/ diakses pada 17-012020 pukul 17.15 WIB.

Om.Makplus. 2015. "Definisi dan Pengertian Baitul mal Wattamwil (BMT)", diakses dari http://www.definisi- 
pengertian.com/2015/05/definisi-

pengertian-baitul-mal-

wattamwil.html?m=1, pada tanggal 17

Januari 2020 pukul 16.20. 